\title{
PENGARUH IMPLEMENTASI PENDEKATAN SAINTIFIK DENGAN METODE PQ4R TERHADAP MINAT LITERASI HUMANISTIK DAN HASIL BELAJAR IPA SISWA KELAS IV SD GUGUS II TEJAKULA TAHUN PELAJARAN 2019/2020
}

\author{
K. Partami ${ }^{1}$, I.B.P. Arnyana ${ }^{2}$, I.B. Putrayasa ${ }^{3}$ \\ ${ }^{123}$ Program Studi Pendidikan Dasar \\ Universitas Pendidikan Ganesha \\ Singaraja, Indonesia \\ e-mail: ketut.partrami@undiksha.ac.id ${ }^{1}$, putu.arnyana@undiksha.ac.id ${ }^{2}$, \\ bagus.putrayasa@undiksha.ac.id ${ }^{3}$
}

\begin{abstract}
Abstrak
Penelitian ini bertujuan untuk mengetahui pengaruh implementasi pendekatan saintifik dengan metode PQ4R terhadap minat literasi humanistik dan hasil belajar IPA siswa kelas IV SD Gugus II Tejakula Tahun Pelajaran 2019/2020. Penelitian ini merupakan penelitian ekperimen semu dengan rancangan penelitian yang digunakan adalah non equivalent post-test only control group design. Populasi dalam penelitian 172 orang siswa. Sampel sebanyak 79 orang siswa diperoleh dengan teknik random sampling. Data minat literasi humanistik dikumpulkan dengan kuesioner dan data hasil belajar IPA dikumpulkan dengan tes objektif. Analisis data menggunakan analisis Manova. Berdasarkan analisisi data penelitian didapatkan hasil bahwa: 1) terdapat pengaruh implementasi pendekatan saintifik dengan metode PQ4R terhadap minat literasi humanistik siswa kelas IV SD Gugus II Tejakula Tahun Pelajaran 2019/2020, 2) terdapat pengaruh implementasi pendekatan saintifik dengan metode PQ4R terhadap hasil belajar IPA siswa kelas IV SD Gugus II Tejakula Tahun Pelajaran 2019/2020, 3) secara simultan, terdapat pengaruh implementasi pendekatan saintifik dengan metode PQ4R secara bersama-sama terhadap minat literasi humanistik dan hasil belajar IPA siswa kelas IV SD Gugus II Tejakula Tahun Pelajaran 2019/2020. Berdasarkan hasil penelitian tersebut, dapat disimpulkan terdapat pengaruh implementasi pendekatan saintifik dengan metode PQ4R terhadap minat literasi humanistik dan hasil belajar IPA siswa kelas IV SD Gugus II Tejakula Tahun Pelajaran 2019/2020.
\end{abstract}

Kata Kunci : Hasil Belajar; Metode PQ4R; Minat Literasi Humanistik; Pendekatan Saintifik

\section{Abstract}

This study aims to determine the effect of the implementation of the scientific approach with the PQ4R method to the interest of humanistic literacy and science learning outcomes of fourth grade students in the Elementary School Group II Tejakula 2019/2020 Academic Year. This research is a quasiexperimental study with the research design used is non equivalent post-test only control group design. The population in the study was 172 students. A sample of 79 students was obtained by random sampling technique. Data on interest in humanistic literacy was collected by questionnaire and data on learning outcomes of Natural Sciences was collected by objective tests. Data analysis using Manova analysis. Based on the analysis of research data, the results show that: 1) there is an influence of the implementation of the scientific approach with the PQ4R method to the interest in humanistic literacy of the fourth grade students of the Tugakula II Elementary School Cluster 2019/2020, 2) there is an influence of the implementation of the scientific approach with the PQ4R method Class IV SD Tejakula Cluster 2019/2020 Academic Year, 3) Simultaneously, there is an effect of the implementation of the scientific approach with the PQ4R method together on the interest in humanistic literacy and the learning outcomes of the fourth grade students of Class II Cluster Tejakula in the 2019/2020 Academic Year. Based on these results, it can be concluded that there is an influence of the implementation of the scientific approach with the PQ4R method to the interest in humanistic literacy and science learning outcomes of fourth grade students in the Elementary School Group II Tejakula 2019/2020 Academic Year.

Keywords : Learning Outcomes; PQ4R Methods; Humanistic Literacy Interests; Scientific Approaches 


\section{PENDAHULUAN}

Dalam pembelajaran IPA sangat diperlukan inovasi - inovasi yang mendukung siswa dalam belajar sehingga mampu meningkatkan minat dan motivasi siswa untuk belajar. Jika pembelajaran sudah berlangsung dengan baik dan sesuai dengan tuntutan pembelajaran di abad 21 serta tuntutan kurikulum k13 maka minat siswa akan semakin tinggi untuk belajar dan menggali informasi lebih dalam. Informasi-informasi yang diperoleh oleh siswa berawal dari proses membaca yang saat ini dikenal dengan literasi.

Kegiatan literasi saat ini sudah digencarkan oleh pemerintah dalam dunia pendidikan yang sering disebut Gerakan Literasi Sekolah (GLS). Pembelajaran literasi yang dikenal dengan istilah GLS merupakan suatu upaya dalam mencapai salah satu dari Sembilan agenda prioritas (Nawacita) yaitu melakukan revolusi karakter bangsa. Menurut Kementerian Pendidikan dan Kebudayaan, (2016:2) pengertian literasi adalah kemampuan mengakses, memahami, dan menggunakan sesuatu melalui berbagai aktivitas, antara lain membaca, melihat, menyimak, menulis, dan berbicara.

Oktavianti, dkk (2017) Gerakan Literasi Sekolah (GLS) digagas dan dikembangkan Direktorat Jenderal Pendidikan Dasar dan Menengah yang merupakan kepedulian atas rendahnya kompetensi peserta didik Indonesia. Upaya ini dilakukan sesuai dengan Rencana Pembangunan Jangka Menengah Nasional (RPJM) 2015-2019 salah satunya yaitu revolusi karakter bangsa. Dalam mengembangkan pendidikan berbasis karakter, kurikulum mengadopsi kearifan lokal yang sesuai dengan bakat serta potensi peserta didik. Literasi merupakan kemampuan mengimplementasikan pengetahuan yang dimiliki siswa untuk menyelesaikan masalah-masalah di kehidupan nyata (Windyariani, 2016).

Untuk mencapai peserta didik yang literat kaya dengan ilmu pengetahuan sesuai dengan tuntutan kurikulum saat ini, maka sangat diperlukan pembelajaran yang berkualitas. Hal inilah yang menjadi tantangan bagi para guru untuk membekali para siswanya dengan berbagai pengetahuan ketrampilan dan sikap, guna mempersiapkan siswa agar memiliki kecakapan hidup yaitu fleksibilitas dan adaptabilitas, inisiatif dan mandiri, mampu berinteraksi lintas sosial budaya, produktifitas dan akuntabilitas serta sikap kepemimpinan dan tanggung jawab. Di samping hal-hal tersebut, siswa juga harus memiliki karakter moral yang kuat, seperti cinta tanah air, memiliki nilai-nilai budi pekerti luhur, jujur, adil, empati, penyayang, rasa hormat dan kesederhanaan, pengampun dan rendah hati. Kegiatan literasi bisa dilakukan oleh guru dengan berbagai inovasi dan kreasi sehingga siswa tidak bosan dengan pembelajaran yang monoton. Literasi yang bagus dilakukan oleh guru yaitu dengan lebih mementingkan isi yang dipelajari dari pada proses belajar itu sendiri. Pernyataan tersebut merupakan teori humanistik yang sering diartikan sebagai teori belajar yang lebih tertarik pada pengertian belajar dalam bentuknya yang paling ideal dari pada pemahaman tentang proses belajar sebagaimana apa adanya, seperti yang selama ini dikaji oleh teoriteori belajar lainnya. Oleh karena itu melalui proses pembelajaran minat literasi humanistik peserta didik harus meningkat.

Disamping meningkatnya minat literasi humanistik peserta didik, hasil belajar siswa juga harus meningkat setelah mereka melakukan proses belajar. Susanto, (2007:5) menyatakan bahwa "hasil belajar adalah perubahan perubahan yang terjadi pada diri siswa, baik yang menyangkut aspek kognitif, afektif, psikomotor sebagai hasil belajar dari kegiatan belajar". Menurut Purwanto (dalam Astiti, 2017) menyatakan bahwa hasil belajar adalah suatu yang digunakan untuk menilai hasil pelajaran yang telah diberikan kepada siswa dalam waktu tertentu. Sementara menurut Bundu (dalam Wahida, 2016:2) yang menyatakan bahwa "hasil belajar dapat diartikan sebagai tingkat penguasaan yang dicapai siswa dalam mengikuti program belajar mengajar sesuai dengan tujuan pendidikan yang ditetapkan meliputi aspek 
kognitif, afektif dan psikomotorik". Secara sederhana yang dimaksud dengan hasil belajar siswa adalah kemampuan yang diperoleh anak setelah melalui kegiatan belajar.

Menurut Wianataputra (2008:15) menyatakan bahwa "belajar sebagai proses manusiawi memiliki kedudukan dan peran penting, baik dalam kehidupan masyarakat tradisional maupun masyarakat modern". Seorang siswa dikatakan belajar bila pikiran dan perasaannya aktif dan mengalami perubahan baik tingkah laku maupun hasil belajarnya.

Kenyataan dilapangan ditemukan bahwa minat literasi humanistik dan hasil belajar siswa belum optimal. Hal ini sesuai dengan hasil observasi yang telah dilakukan dengan hasil yaitu, 1) pembelajaran di kelas belum menggunakan model pembelajaran yang inovatif melainkan guru masih menggunakan metode pembelajaran yang lama, 2) proses pembelajaran masih berpusat pada guru sehingga jarang memberikan kesempatan kepada siswa untuk memahami fenomena-fenomena disekitarnya sesuai dengan tuntutan kurikulum 2013, 3) minat literasi humanistik siswa rendah, 4) hasil belajar IPA siswa rendah karena masih banyak dibawah KKM, 5) dalam pembelaran jarang menggunakan media pembelajaran, 6) metode pembelajaran kurang bervariasi sehingga siswa bosan dalam belajar.

Setelah dilakukan observasi dilanjutkan dengan melakukan wawancara. Berdasarkan wawancara yang dilakukan diketahui minat literasi humanistik dan hasil belajar IPA siswa masih rendah. Faktor yang menyebabkan rendahnya minat literasi humanistik dan hasil belajar siswa karena 1) kurangnya minat siswa untuk belajar, 2) siswa kurang termotivasi untuk belajar dan menganggap mata pelajaran IPA adalah mata pelajaran yang kurang menarik, 3) serta siswa belum mampu mengaitkan pembelajaran di kelas dengan lingkungan sekitarnya, 4) kurangnya buku - buku pelajaran yang menunjang kegiatan pembelajaran.

Menyikapi masalah rendahnya minat literasi humanistik dan hasil belajar IPA siswa, perlu diupayakan usaha peningkatan penguasaan siswa terhadap konsep-konsep IPA melalui suatu model pembelajaran yang kelihatannya lebih berpusat pada upaya menumbuhkembangkan partisipasi dan aktivitas siswa (student center) sesuai tuntutan kurikulum 2013. Upaya lain yang dapat dilakukan yaitu meningkatkan keterampilan proses sains serta mampu meningkatkan kemampuan pemecahan masalah siswa sehingga kegiatan pembelajaran tidak lagi hanya mengutamakan produk saja tetapi lebih mengutamakan proses bagaimana pengetahuan tersebut diperoleh siswa.

Salah satu upaya meningkatkan proses yang ditinjau dari minat literasi humanistik dan hasil belajar IPA siswa adalah dengan mengujicobakan pendekatan saintifik bermuatan metode pembelajaran PQ4R. Metode merupakan salah satu strategi atau cara yang digunakan oleh guru dalam proses pembelajaran yang hendak dicapai, semakin tepat metode yang digunakan oleh seorang guru maka pembelajaran akan semakin baik. Metode berasal dari kata methodos dalam bahasa yunani memiliki arti cara atau jalan. Kamus Besar Bahasa Insonesia (2001:704) mengartikan bahwa metode merupakan cara teratur yang digunakan untuk melaksanakan suatu pekerjaan agar tercapai sesuai dengan yang dikehendaki. Secara harfiah metode berarti cara dalam pemakaian yang umum, metode diartikan sebagai suatu cara atau prosedur yang dipakai untuk mencapai tujuan tertentu.

Metode PQ4R digunakan sebagai salah satu alternatif pembelajaran bermakna yang bermuara pada pembelajaran yang aktif, kreatif, efektif dan menyenangkan. Menurut Weinstein dan Meyer (Trianto, 2007), pengajaran yang baik meliputi pengajaran siswa bagaimana belajar, bagaimana mengingat, bagaimana berfikir dan bagaimana memotivasi diri mereka sendiri. Hal inilah yang menjadikan strategi pembelajaran mutlak untuk diterapkan dari Sekolah Dasar dan terus berlanjut sampai sekolah dan pendidikan tinggi.

Menurut Supriya (2009) PQ4R (Preview, Quention, Read, Reflect, Recite 
and Review) adalah suatu metode pembelajaran yang merupakan bagian dari metode kooperatif learning yang bertujuan untuk meningkatkan daya paham dan daya ingat siswa tentang materi yang mereka baca dengan cara membaca dan menulis. Menurut Trianto (2010:150) metode pembelajaran PQ4R adalah salah satu bagian dari startegi elaboratif. Metode pembelajaran PQ4R dapat digunakan untuk membantu siswa mengingat apa yang siswa baca dan dapat membantu proses pembelajaran kelas yang dilaksanakan dengan membaca buku pelajaran secara berkelompok. Siswa diminta untuk mengeksplorasi kemampuannya membuat struktur berpikir sebelum membaca dengan menyusun pertanyaan-pertanyaan yang menjadi acuan bagi siswa untuk menggali informasi yang dibutuhkan dari teks bacaan. Kemudian siswa secara mandiri membaca teks sambil mencari jawaban dari pertanyaan yang telah dibuatnya.

Metode pembelajaran PQ4R memiliki kelebihan seperti halnya metodemetode pembelajaran yang lainya. (Puspita, 2015) mengemukakan bahwa kelebihan metode PQ4R yaitu: sangat tepat digunakan dalam pengajaran pengetahuan yang bersifat deklaratif berupa konsep-konsep, definisi, kaidahkaidah, dan pengetahuan penerapan dalam kehidupan sehari-hari, dapat membantu siswa yang daya ingatnya lemah untuk menghapal konsep-konsep pelajaran, mudah diterapkan pada semua jenjang pendidikan, mampu membantu siswa dalam meningkatkan keterampilan proses bertanya dan mengomunikasikan pengetahuannya, dan dapat menjangkau materi pelajaran dalam cakupan yang luas.

Metode pembelajaran PQ4R telah banyak diteliti oleh para peneliti. Adapun hasil penelitian yang relevan terkait dengan penelelitian yang akan dilakukan adalah penelitian yang dilakukan oleh Miftakhurrofi'ah (2018) dengan judul penelitian "Pengaruh Perangkat Pembelajaran Berbasis Strategi PQ4R Terhadap Motivasi Dan Hasil Belajar Kognitif Peserta Didik". Hasil yang diperoleh dalam penelitian tersebut adalah dengan diterapkannya strategi PQ4R mampu mengubah pola pembelajaran menjadi student centered learning dan memfasilitasi peserta didik untuk lebih aktif dalam pembelajaran dengan kegiatan meninjau bacaan, bertanya, membaca, merefleksi materi, mengungkapkan gagasan dan mengulas kembali sehingga motivasi dan hasil belajar kognitif peserta didik dapat meningkat.

Penelitian yang dilakukan oleh Rikmasari (2018) dengan penelitiannya yang berjudul "Metode Pembelajaran PQ4R dalam Meningkatkan Kemampuan Membaca Pemahaman Siswa Kelas V di Bekasi". Dengan diterapkannya model pembelajaran PQ4R dalam penelitian tersebut dapat mengaktifkan pengetahuan awal siswa ketika membaca sekilas, serta membantu siswa memahami isi bacaan lebih mudah dengan melakukan tahapan PQ4R yaitu (preview, question, read, reflect, recite, review), metode PQ4R juga sangat cocok untuk meningkatkan kemampuan membaca pemahaman, yaitu di setiap tahapan pembelajarannya mampu memotivasi siswa untuk mencari, mengingat, dan memahami informasi yang didapat dari hasil membaca cerita atau bahan bacaan lainnya.

Penelitian serupa juga dilakukan oleh Faradita (2019) dengan penelitiannya yang berjudul "Peningkatan Hasil Belajar IPA di SD dengan Menggunakan Metode PQ4R". Dengan menggunakan metode PQ4R dalam pembelajaran dapat meningkatkan hasil belajar IPA siswa kelas V Al-Kholiq SD Muhammadiyah 8 Surabaya. Dalam kaitannya penelitian yang dilakukan oleh Farandita dengan penelitian ini, sama-sama menggunakan metode PQ4R dan melihat pengaruhnya tehadap hasil belajar IPA di SD. Perbedaannya dalam penelitian ini, selain untuk mengetahui pengaruhnya terhadap hasil belajar IPA, dalam penelitian ini dilihat juga pengaruhnya terhadap variabel lain, yaitu minat literasi humanistik.

Berdasarkan penjelasan di atas, maka perlu dilakukan suatu penelitian eksperimen dengan judul "Pengaruh Implementasi Pendekatan Saintifik dengan Metode PQ4R terhadap Minat Literasi Humanistik dan Hasil Belajar IPA Siswa 
Kelas IV SD Gugus II Tejakula Kecamatan Tejakula Tahun Pelajaran 2019/2020".

Tujuan dalam penelitian ini adalah; (1) untuk mengetahui dan mendeskripsikan pengaruh implementasi pendekatan saintifik dengan metode PQ4R terhadap minat literasi humanistik siswa kelas IV SD Gugus II Tejakula Tahun Pelajaran 2019/2020; (2) untuk mengetahui dan mendeskripsikan pengaruh implementasi pendekatan saintifik dengan metode PQ4R terhadap hasil belajar IPA siswa kelas IV SD Gugus II Tejakula Tahun Pelajaran 2019/2020; (3) ntuk mengetahui dan mendeskripsikan pengaruh implementasi pendekatan saintifik dengan metode PQ4R secara bersama-sama terhadap minat literasi humanistik dan hasil belajar IPA siswa kelas IV SD Gugus II Tejakula Tahun Pelajaran 2019/2020.

\section{METODE}

Penelitian ini dilakukan pada semester genap tahun pelajaran 2019/2020 pada siswa kelas IV SD di Gugus II Kecamatan Tejakula Kabupaten Buleleng. Jenis penelitian yang dilakukan adalah penelitian eksperimen semu. Penelitian ini bertujuan untuk menguji pengaruh implementasi pendekatan saintifik dengan metode PQ4R terhadap minat literasi humanistik dan hasil belajar IPA Siswa Kelas IV SD Gugus II Tejakula Kecamatan Tejakula. Penelitian ini menggunakan dua kelas, yaitu kelas eksperimen dan kontrol. Kelas eksperimen adalah kelas yang dikenai Pembelajaran Berpendekatan Saintifik dengan Metode PQ4R sedangkan kelas kontrol adalah kelas yang dikenai model pembelajaran konvensional. Penelitian ini merupakan penelitian eksperimen semu dengan rancangan penelitian yang digunakan adalah non equivalent post-test only control group design.

Dalam penelitian terdapat kelas eksperimen dan kelas kontrol. Pada kelas eksperimen diberikan perlakuan atau treatment berupa Pembelajaran Berpendekatan Saintifik dengan Metode PQ4R. Sedangkan pada kelas kontrol mendapatkan perlakuan tidak menggunakan Pembelajaran Berpendekatan Saintifik saja. Pada akhir pertemuan dikelas eksperimen dan kelas kontrol sama-sama diberikan post-test, beberapa test objektif yaitu pilihan ganda untuk minat literasi humanistik dan hasil belajar IPA. Penelitian ini terdiri dari tiga tahapan yaitu tahap persiapan, tahap pelaksanaan, dan tahap akhir penlitian.

Populasi adalah keseluruhan objek dalam satuan penelitian. Populasi dalam penelitian ini adalah seluruh siswa kelas IV SD Gugus II Kecamatan Tejakula yang berjumlah 172 siswa. Menurut Agung (2014: 69) sampel adalah "sebagian dari populasi yang diambil, yang dianggap mewakili seluruh populasi dan diambil dengan menggunakan teknik tertentu". Dapat dikatakan bahwa sampel adalah sebagian dari populasi yang dianggap mewakili seluruh populasi dan diambil dengan menggunakan teknik tertentu. Teknik yang dilakukan dalam pemilihan sampel dalam penelitian ini ialah random sampling dengan teknik undian. Cara ini dilakukan karena tidak mungkin mengubah atau mengacak individu, jadi yang dapat dipilih secara acak yakni kelas ataupun kelompok. Kelas dipilih sebagaimana telah terbentuk tanpa campur tangan peneliti. Selanjutnya akan dilakukan penentuan sampel. Sebelum dilakukan penentuan sampel penelitian, dilakukan uji kesetaraan pada semua sekolah yang ada Siswa Kelas IV SD Gugus II Tejakula Kecamatan Tejakula Data yang digunakan dalam uji kesetaraan adalah nilai ulangan akhir semester (UAS) ganjil mata pelajaran IPA kelas IV Sekolah Dasar. Secara keseluruhan untuk menguji kesetaraan nilai hasil ulangan akhir semester ganjil siswa kelas IV Gugus II Tejakula Kecamatan Tejakula menggunakan Anova.

Uji kesetaraan yang dilakukan menggunakan bantuan SPSS 17.0 for Windows dengan signifikansi 5\%. Jika signifikansi (sig) > 0,05, maka $\mathrm{H} 0$ diterima. Semua populasi dijadikan sampel untuk dijadikan kelas setara dilakukan uji kesetaraan. Sebelum diadakan pengambilan sampel, terlebih dahulu dilakukan pengujian kesetaraan kelas berdasarkan tes awal yang diberikan kepada siswa, untuk lebih meyakinkan kedua kelompok yang menjadi sampel tidak berbeda secara signifikan. Skor dari 
tes tersebut kemudian dianalisis dengan menggunakan uji Anava satu arah. Berdasarkan uji kesetaraan yang telah dilakukan dengan bantuan aplikasi SPSS 17.0 for Windows diketahui bahwa nilai $F$ $=1,672$ dan nilai signifikansi nilai IPA siswa pada populasi tersebut adalah 0,162 lebih besar dari 0,05 . Hal ini menunjukkan bahwa kemampuan siswa dari kedelapan sekolah siswa kelas IV di SD Gugus II Kecamatan Tejakula, Kabupaten Buleleng dinyatakan dalam kondisi setara secara signifikan. Setelah diketahui bahwa seluruh kelompok memiliki kemampuan setara, selanjutnya dilakukan pengundian untuk menentukan kelompok eksperimen dan kelompok kontrol. Berdasarkan pengundian yang telah dilakukan, didapatkan hasil bahwa SDN 3 Les dan SDN 1 Les sebagai kelas eksperimen dan SDN 4 Penuktukan dan SDN 2 Les sebagai kelas Kontrol. Sampel dalam penelitian ini berjumlah 79 siswa.

Variabel merupakan sesuatu yang berupa konsep yang akan menjadi titik fokus penelitian untuk dipelajari sehingga memperoleh informasi tentang hal tersebut, lalu ditarik kesimpulannya. Pada penelitian ini melibatkan dua variable yakni variabel bebas dan variabel terikat. Variabel bebas dalam penelitian ini berkaitan dengan model pembelajaran, yakni: a) Pendekatan Saintifik dengan Metode PQ4R dan b) model pembelajaran konvensional. Variabel terikat dalam penelitian ini adalah minat literasi humanistik dan hasil belajar IPA siswa.

Penelitian ini dilakukan selama 8 kali pertemuan. Adapun data pada penelitian ini dikumpulkan dengan beberapa metode pengumpulan data yang disesuaikan dengan permasalahan yang dikaji pada penelitian ini. Sesuai dengan permasalahannya maka data yang diperlukan, yaitu minat literasi humanistik dan hasil belajar. Dalam penelitian ini data pemahaman diperoleh melalui pemberian kuisioner dan tes objektif tipe tes pilihan ganda. Dalam penelitian ini menggunakan instrumen sesuai dengan jenis data dan sifat data yang akan dicari. Alat pengumpul data harus memenuhi persyaratan yaitu syarat validitas dan reliabilitas dalam mengungkap apa yang hendak diukur. Ada dua persyaratan yang hendak digunakan dalam pengumpulan data penelitian yaitu validitas dan reliabilitas. Validitas instrumen dalam penelitian ini meliputi dua segi yaitu validitas isi dan validitas butir. Validitas isi dibantu oleh dua orang ahli/ expert, kemudian dianalisis dengan teknik Gregory.

Sebelum instrumen digunakan, maka perlu diuji dahulu validitas dari masing-masing pertanyaan yang ada sebagai alat pengambilan data. Dengan demikian terlebih dahulu diadakan uji coba terhadap kuisioner kemudian hasil uji coba ini dianalisis. Kriteria yang digunakan dalam validitas adalah dengan membandingkan harga dengan tabel harga $r$ product moment pada taraf signifikansi $5 \%$. Tes dikatakan valid jika $r p b i>r$ pada taraf signifikansi $5 \%$. Tes yang divalidasi oleh para ahli dapat diketahui butir yang sesuai dan yang tidak sesuai. Begitu juga dapat diketahui upaya perbaikan untuk butir-butir tes yang sesuai. Pengujian terhadap reabilitas instrumen dilakukan melalui pendekatan ketetapan internal. Koyan (2011) reliabilitas alat ukur adalah keterandalan alat ukur atau keajegan alat ukur; artinya, kapanpun alat ukur itu digunakan akan menghasilkan hasil ukur yang relatif tetap. Untuk menentukan derajat reliabilitas tes, dapat digunakan kriteria yang dikemukakan oleh Guilford, 1951. Data yang telah diperoleh dari penelitian dideskripsikan menurut masing-masing variable. Oleh tujuannya seperti itu, maka akan dicari harga rerata (M), standar deviasi (SD), modus (Mo), dan median (Me) setiap variabel yang diteliti.

Data yang dikumpulkan dalam penelitian ini adalah data minat literasi humanistik dan hasil belajar IPA siswa kelas IV. Dalam penelitian ini digunakan analisis varian yang disingkat Manova."Uji Manova digunakan untuk menguji apakah terdapat perbedaan beberapa variabel terikat antara beberapa kelompok yang berbeda" (Candiasa, 2010:39).Variabel bebas dalam penelitian ini adalah Pendekatan Saintifik dengan Metode PQ4R dengan dua variabel terikat yaitu minat literasi humanistik dan hasil belajar IPA. Data hasil penelitian yang telah dikumpulkan akan dianalisis secara 
bertahap yakni deskripsi data, uji prasyarat analisis dan uji hipotesis. Adapun uji prasyarat yang dilakukan adalah uji normalitas sebaran data, uji homogenitas varians, dan uji korelasi antar variabel terikat.

\section{HASIL DAN PEMBAHASAN}

Data dalam penelitian ini dikelompokkan menjadi: 1) minat literasi humanistik siswa yang mengikuti pendekatan saintifik dengan Metode PQ4R, 2) hasil belajar IPA siswa yang mengikuti pembelajaran dengan pendekatan saintifik dengan Metode PQ4R, 3) minat literasi humanistik siswa yang mengikuti pembelajaran dengan pembelajaran konvensional, 4) hasil belajar IPA siswa yang mengikuti pembelajaran dengan pembelajaran konvensional.

Selanjutnya dilakukan perhitungan sentral dari masing-masing data untuk mencari mean, median, modus, serta standar deviasi dari tiap-tiap kelompok data tersebut. Perhitungan tersebut dapat dilihat pada Tabel 1.

Tabel 1. Rekapitulasi Hasil Perhitungan Skor Minat Literasi Humanistik dan Hasil Belajar IPA

\begin{tabular}{lrrrr}
\hline Variabel & $\mathrm{A}_{1} \mathrm{Y}_{1}$ & $\mathrm{~A}_{1} \mathrm{Y}_{2}$ & $\mathrm{~A}_{2} \mathrm{Y}_{1}$ & $\mathrm{~A}_{2} \mathrm{Y}_{2}$ \\
\hline $\mathrm{N}$ & 40 & 40 & 39 & 39 \\
Mean & 166,52 & 15,75 & 150,56 & 12,74 \\
Median & 167,50 & 16 & 151 & 13 \\
Modus & 168 & 17 & 153 & 13 \\
Standar Deviasi & 5,64 & 2,28 & 6,08 & 2,12 \\
Varians & 31,79 & 5,22 & 36,94 & 4,51 \\
Rentangan & 22 & 10 & 24 & 9 \\
Skor Minimum & 155 & 10 & 139 & 8 \\
Skor Maksimum & 177 & 20 & 163 & 17 \\
Jumlah & 6661 & 630 & 5872 & 497 \\
\hline
\end{tabular}

Keterangan:

$\mathrm{A}_{1} \mathrm{Y}_{1}=$ Minat literasi humanistik siswa yang mengikuti pendekatan saintifik dengan metode PQ4R

$\mathrm{A}_{1} \mathrm{Y}_{2}=$ Hasil belajar IPA siswa yang mengikuti pendekatan saintifik dengan metode PQ4R

$\mathrm{A}_{2} \mathrm{Y}_{1}=$ Minat literasi humanistik siswa yang mengikuti pembelajaran dengan pembelajaran konvensional.

$\mathrm{A}_{2} \mathrm{Y}_{2}=$ Hasil belajar IPA siswa yang mengikuti pembelajaran dengan pembelajaran konvensional.

Pengaruh implementasi pendekatan saintifik dengan metode PQ4R terhadap minat literasi humanistik siswa kelas IV SD Gugus II Tejakula Tahun Pelajaran 2019/2020

Hasil uji hipotesis pertama menunjukkan terdapat perbedaan minat literasi humanistik antara kelompok siswa yang mengikuti pendekatan saintifik dengan metode PQ4R dengan kelompok siswa yang mengikuti pembelajaran konvensional. Hasil penelitian menunjukkan bahwa minat literasi humanistik siswa yang mengikuti pembelajaran dengan pendekatan saintifik dengan metode PQ4R lebih baik dibandingkan dengan minat literasi humanistik siswa yang belajar dengan model konvensional pada kelas IV SD Gugus II Tejakula Tahun Pelajaran 2019/2020. Hal ini ditunjukkan dengan rata-rata minat literasi humanistik siswa yang mengikuti pendekatan saintifik dengan Metode PQ4R lebih tinggi daripada minat literasi humanistik siswa yang mengikuti model konvensional.

Berdasarkan data hasil analisis multivariat dengan bantuan SPSS-17.00 for windows diperoleh nilai signifikansi lebih kecil dari 0,05, sehingga dapat ditarik simpulan bahwa terdapat perbedaan yang signifikan antara minat literasi humanistik siswa yang belajar dengan pendekatan 
saintifik dengan metode PQ4R dengan minat literasi humanistik siswa yang belajar dengan model konvensional. Jadi dalam perbandingan antara pendekatan saintifik dengan metode PQ4R dengan model konvensional, terdapat pengaruh model pembelajaran terhadap minat literasi humanistik siswa. Dengan kata lain, ada perbedaan antara pendekatan saintifik dengan metode PQ4R dengan pembelajaran konvensional.

Berdasarkan data hasil analisis tersebut, secara teoritis dapat dikatakan bahwa penggunaan pendekatan saintifik dengan Metode PQ4R lebih baik dan efektif untuk meningkatkan minat literasi humanistik siswa dalam proses pembelajaran. Pembelajaran pada hakikatnya adalah proses interaksi antara guru dengan siswa, siswa dengan siswa, dan siswa dengan lingkungannya. Berdasarkan hakikat pembelajaran tersebut, maka guru sebagai fasilitator dalam perencanaan dan pelaksanaan pembelajaran memegang peranan penting, karena ketepatan guru dalam memilih pendekatan pembelajaran baik pada saat perencanaan dan pelaksanaan pembelajaran sangat berpengaruh terhadap proses dan hasil belajar siswa. Model pembalajaran konvensional yang masih sering digunakan guru dalam perencanaan dan proses pembelajaran, belum menunjukkan adanya interaksi siswa, baik secara fisik dan mental.

Pendekatan saintifik merupakan pendekatan yang mengadopsi langkah langkah saintis dalam membangun pengetahuan melalui metode ilmiah. Adapun langkah-langkah pendekatan saintifik yaitu, mengamati (observing), menanya (questioning), mencoba (applying), menalar (sinteshis), dan mengomunikasikan (communication).

Pendekatan saintifik akan lebih baik jika diintegrasikan dengan metode PQ4R. Metode PQ4R merupakan bagian dari strategi elaborasi. Strategi elaborasi adalah proses penambahan perincian sehingga informasi baru menjadi lebih bermakna, oleh karena itu membuat pengkodean lebih mudah dan lebih memberkan kepastian Widiyanthi (2015). Metode PQ4R merupakan metode yang digunakan untuk membantu siswa mengingat apa yang mereka baca dan dapat membantu proses belajar mengajar di kelas yang dilaksanakan dengan kegiatan membaca buku.

Temuan dalam penelitian ini sejalan dengan hasil penelitian yang dilakukan oleh Wana dan Pradistia (2018). Judul penelitiannya adalah Implementasi Pendekatan Saintifik Untuk Meningkatkan Budaya Literasi Di Sekolah Dasar. Hasil penelitian ini adalah telah dilaksanakan progam implementasi pendekatan saintifik dalam meningkatkan budaya literasi di SDN Kincang 02. Upaya-upaya yang dilakukan sekolah dalam melaksanakan program gerakan literasi sekolah adalah: (1) menambah buku pengayaan, (2) mendekatkan buku ke peserta didik dengan cara membuat area baca dan lingkungan yang kaya akan teks, (3) melaksanakan berbagai bentuk kegiatan literasi, dan (4) melibatkan publik dalam pelaksanaan gerakan literasi. (5) Pihak sekolah sudah memiliki hubungan komunikasi yang baik dengan orang tua dalam hal memberikan motivasi belajar pada anak. Adapun kendala yang dihadapi sekolah dalam pelaksanaan Gerakan Literasi ini adalalah: (1) rendahnya kesadaran guru, (2) buku pengayaan yang sesuai dengan kebutuhan anak sulit ditemukan, (3) guru malas membaca, (4) guru tidak memahami penerapan gerakan literasi, dan (5) sekolah kekurangan dana. Dengan demikian, implementasi pendekatan saintifik pada gerakan literasi sekolah di SDN Kincang 02 perlu ditingkatkan ke tahap pengembangan dengan melibatkan berbagai pihak.

Berdasarkan hasil analisis dan temuan dalam penelitian lain yang sesuai dengan penelitian ini, jadi dapat disimpulkan bahwa terdapat perbedaan minat literasi humanistik antara siswa yang mengikuti pembelajaran pendekatan saintifik dengan metode PQ4R dengan siswa yang mengikuti pembelajaran konvensional pada siswa kelas IV SD Gugus II Tejakula Tahun Pelajaran 2019/2020.

\section{Pengaruh implementasi pendekatan saintifik dengan metode PQ4R terhadap hasil belajar IPA siswa kelas IV SD}




\section{Gugus II Tejakula Tahun Pelajaran 2019/2020}

Hasil uji hipotesis kedua menunjukkan terdapat perbedaan hasil belajar IPA antara siswa yang mengikuti pembelajaran pendekatan saintifik dengan metode PQ4R dengan siswa yang mengikuti pembelajaran konvensional. Hasil penelitian menunjukkan bahwa hasil belajar IPA siswa yang mengikuti pembelajaran dengan pendekatan saintifik dengan metode PQ4R lebih baik dibandingkan dengan hasil belajar IPA siswa yang belajar dengan model konvensional pada siswa kelas IV SD Gugus II Tejakula Tahun Pelajaran 2019/2020. Hal ini ditunjukkan dengan rata-rata hasil belajar IPA siswa yang mengikuti pendekatan saintifik dengan metode PQ4R lebih tinggi daripada hasil belajar IPA siswa yang mengikuti pembelajaran konvensional.

Berdasarkan data hasil penelitian analisis multivariat dengan berbantuan SPSS-17.00 for windows diperoleh nilai signifikansi lebih kecil dari 0,05, sehingga dapat ditarik kesimpulan bahwa terdapat perbedaan yang signifikan antara hasil belajar IPA siswa yang mengikuti pembelajaran dengan pendekatan saintifik dengan metode PQ4R dengan hasil belajar siswa yang mengikuti pembelajaran konvensional. Jadi dalam perbandingan antara pendekatan saintifik dengan metode PQ4R dengan pembelajaran konvensional, terdapat pengaruh pendekatan pembelajaran terhadap hasil belajar IPA siswa.

Melihat data hasil penelitian tersebut, secara teoritis dapat dikatakan bahwa hasil belajar IPA siswa yang mengikuti pendekatan saintifik dengan metode PQ4R lebih baik dan efektif. Proses dan hasil dari sebuah pembelajaran, salah satunya diukur dari seberapa jauh siswa memahami materi atau konsep dari sebuah materi. Pembelajaran yang melibatkan siswa secara aktif, baik aktif fisik dan mental, akan membantu dan memudahkan siswa dalam memahami sebuah konsep selama proses dan setelah proses pembelajaran. Pembelajaran yang dilaksanakan oleh pihak guru selama ini masih menggunakan paradigma lama yaitu teacher center, guru masih mendominasi kegiatan pembelajaran dan belum melibatkan siswa dalam interaksi belajar sehingga aktivitas fisik dan mental sosial siswa belum optimal dan berdampak pada tingkat pemahaman siswa terhadap sebuah konsep materi yang sedang dan telah dipelajari.

Pendekatan saintifik akan lebih baik jika diintegrasikan dengan metode PQ4R. Metode PQ4R merupakan bagian dari strategi elaborasi. Strategi elaborasi adalah proses penambahan perincian sehingga informasi baru menjadi lebih bermakna, oleh karena itu membuat pengkodean lebih mudah dan lebih memberkan kepastian.

Temuan dalam penelitian ini sejalan dengan hasil penelitian yang dilakukan oleh Wijayanto (2018). Judul penelitiannya Implementasi Model Pembelajaran PQ4R Dengan Pendekatan Saintifik Pada Peningkatan Kemampuan Pemecahan Masalah Matematis Siswa. Hasil penelitian menunjukkan bahwa: (1) desain model pembelajaran PQ4R dengan Pendekatan Saintifik yang dilaksanakan di kelas VIII SMP Negeri 39 Semarang pada peningkatan kemampuan pemecahan masalah matematis siswa dengan enam tahapan dan (2) implementasi model pembelajaran PQ4R dengan Pendekatan Saintifik efektif dalam meningkatkan kemampuan pemecahan masalahmatematis siswa.

Berdasarkan hasil analisis dan temuan dalam penelitian lain yang sesuai dengan penelitian ini, jadi dapat disimpulkan bahwa terdapat perbedaan hasil belajar IPA antara siswa yang mengikuti pembelajaran pendekatan saintifik dengan metode PQ4R dengan siswa yang mengikuti pembelajaran konvensional pada siswa kelas IV SD Gugus II Tejakula Tahun Pelajaran 2019/2020.

Pengaruh implementasi pendekatan saintifik dengan metode PQ4R secara bersama-sama terhadap minat literasi humanistik dan hasil belajar IPA siswa kelas IV SD Gugus II Tejakula Tahun Pelajaran 2019/2020

Hasil uji hipotesis ketiga menunjukkan terdapat perbedaan minat 
literasi humanistik dan hasil belajar IPA secara simultan antara siswa yang mengikuti pembelajaran pendekatan saintifik dengan metode PQ4R dengan siswa yang mengikuti pembelajaran konvensional. Hasil penelitian menunjukkan bahwa minat literasi humanistik dan hasil belajar IPA siswa yang mengikuti pembelajaran dengan pendekatan saintifik dengan metode PQ4R lebih baik dibandingkan dengan minat literasi humanistik dan hasil belajar IPA siswa yang belajar dengan pembelajaran konvensional pada siswa kelas IV SD Gugus II Tejakula Tahun Pelajaran 2019/2020. Hal ini didasarkan pada hasil analisis MANOVA yang menunjukkan bahwa harga $F$ hitung untuk Pillae Trace, Wilk Lambda, Hotelling's Trace, Roy's Largest Root dari implementasi pendekatan saintifik dengan metode PQ4R lebih kecil dari 0,05. Artinya semua nilai Pillae Trace, Wilk Lambda, Hotelling's Trace, Roy's Largest Root signifikan. Dengan demikian, terdapat pengaruh penerapan pendekatan saintifik dengan metode PQ4R terhadap minat literasi humanistik dan hasil belajar IPA secara simultan pada siswa kelas IV SD Gugus II Tejakula Tahun Pelajaran 2019/2020.

Berdasarkan data hasil analisis tersebut, secara teoritis dapat dikatakan bahwa penggunaan pendekatan saintifik dengan metode PQ4R lebih baik dan efektif untuk meningkatkan minat literasi humanistik dan hasil belajar IPA siswa dalam proses pembelajaran.

Pembelajaran mata pelajaran IPA di sekolah dasar memerlukan kiat atau model pembelajaran tertentu yang dapat merangsang motivasi siswa untuk aktif belajar agar materi yang disajikan lebih mudah dipahami siswa. Ini berarti bahwa apabila suatu materi dalam mata pelajaran IPA diajarkan dengan pendekatan dan metode pembelajaran yang menarik bagi siswa, maka materi tersebut akan melekat lama dalam pikiran dan ingatan siswa.

Pendekatan saintifik merupakan pendekatan yang mengadopsi langkah langkah saintis dalam membangun pengetahuan melalui metode ilmiah. Adapun langkah-langkah pendekatan saintifik yaitu, mengamati (observing), menanya (questioning), mencoba (applying), menalar (sinteshis), dan mengomunikasikan (communication). Metode PQ4R merupakan bagian dari strategi elaborasi. Strategi elaborasi adalah proses penambahan perincian sehingga informasi baru menjadi lebih bermakna, oleh karena itu membuat pengkodean lebih mudah dan lebih memberkan kepastian.

Atas uraian tersebut di atas, dapat dikatakan bahwa terdapat perbedaan minat literasi humanistik dan hasil belajar IPA secara simultan antara kelompok siswa yang mengikuti pendekatan saintifik dengan metode PQ4R dengan kelompok siswa yang mengikuti pembelajaran konvensional.

Temuan dalam penelitian ini sejalan dengan penelitian yang dilakukan oleh Astuti (2016) dengan penelitian yang berjudul "Literasi Sains dalam Pembelajaran IPA". Hasil penelitian ini adalah melalui pembelajaran litetasi sains dapat diterapkan sebagai strategi pembelajaran yang dapat mengasah siswa untuk berfikir tinggi terutama dalam pembelajaran IPA dapat meningkatkan pengetahuan hasil belajar terutama konsep-konsep ilmiah maupun teknologi. Dalam kaitannya penelitian yang dilakukan oleh Astuti dengan penelitian ini, samasama mengkaji tentang literasi dalam pembelajaran IPA. Perbedaannya dalam penelitian ini, selain untuk mengetahui pengaruhnya terhadap literasi, dalam penelitian ini dilihat juga pengaruhnya terhadap variabel lain, yaitu hasil belajar IPA. Selain penelitian di atas, penelitian ini juga sejalan dengan hasil penelitian yang dilakukan oleh Juniawan (2020) yang berjudul Pengaruh Pembelajaran Saintifik Berbasis Literasi Terhadap Kemampuan Membaca Pemahaman Dan Hasil Belajar Pelajaran Kelompok Sosial Humaniora Siswa Kelas V SD Di Gugus 1 Kuta. Hasil menunjukkan bahwa terdapat perbedaan kemampuan membaca pemahaman dan perbedaan hasil belajar mata pelajaran kelompok sosial humaniora serta terdapat perbedaan secara simultan terhadap kemampuan membaca pemahaman dan hasil belajar mata pelajaran kelompok sosial humaniora antara kelas eksperimen dengan kelas control. 
Berdasarkan hasil analisis dan temuan dalam penelitian lain yang sesuai dengan penelitian ini, jadi dapat disimpulkan bahwa terdapat perbedaan minat literasi humanistik dan hasil belajar IPA secara simultan antara siswa yang mengikuti pembelajaran pendekatan saintifik dengan metode PQ4R dengan siswa yang mengikuti pembelajaran konvensional pada siswa kelas IV SD Gugus II Tejakula Tahun Pelajaran 2019/2020.

Telah terbukti secara empiris dalam penelitian ini, pertama, terdapat perbedaan minat literasi humanistik antara siswa yang mengikuti pembelajaran dengan pendekatan saintifik dengan metode PQ4R dan siswa yang mengikuti pembelajaran konvensional. Kedua, minat literasi humanistik siswa yang mengikuti pembelajaran dengan pendekatan saintifik dengan metode PQ4R lebih tinggi daripada siswa yang mengikuti pembelajaran konvensional. Ketiga, terdapat perbedaan hasil belajar IPA antara siswa yang mengikuti pembelajaran dengan pendekatan saintifik dengan metode PQ4R dan siswa yang mengikuti pembelajaran konvensional. Keempat, hasil belajar IPA siswa yang mengikuti pembelajaran dengan pendekatan saintifik dengan metode PQ4R lebih tinggi daripada siswa yang mengikuti pembelajaran konvensional.

Dengan pengujian hipotesis yang ketiga terbukti bahwa terdapat perbedaan minat literasi humanistik dan hasil belajar IPA antara siswa yang mengikuti pembelajaran pendekatan saintifik dengan metode PQ4R dengan siswa yang mengikuti pembelajaran konvensional.

Dari uraian di atas dapat disimpulkan bahwa pendekatan saintifik dengan metode PQ4R yang diimplementasikan guru akan sangat mempengaruhi minat literasi humanistik dan hasil belajar IPA siswa, dan pendekatan saintifik dengan metode $P Q 4 R$ dapat meningkatkan minat literasi humanistik dan hasil belajar IPA siswa.

\section{PENUTUP}

$$
\begin{aligned}
& \text { Berdasarkan hasil pengujian } \\
& \text { hipotesis dan pembahasan hasil }
\end{aligned}
$$

penelitian, maka dapat ditarik simpulan sebagai berikut.

a. Terdapat pengaruh implementasi pendekatan saintifik dengan metode PQ4R terhadap minat literasi humanistik siswa kelas IV SD Gugus II Tejakula Tahun Pelajaran 2019/2020.

b. Terdapat pengaruh implementasi pendekatan saintifik dengan metode PQ4R terhadap hasil belajar IPA siswa kelas IV SD Gugus II Tejakula Tahun Pelajaran 2019/2020.

c. Terdapat pengaruh implementasi pendekatan saintifik dengan metode PQ4R secara bersama-sama terhadap minat literasi humanistik dan hasil belajar IPA siswa kelas IV SD Gugus II Tejakula Tahun Pelajaran 2019/2020.

Berdasarkan temuan-temuan tersebut dapat disimpulkan bahwa terdapat pengaruh implementasi pendekatan saintifik dengan metode PQ4R terhadap minat literasi humanistik dan hasil belajar IPA siswa kelas IV SD Gugus II Tejakula Tahun Pelajaran 2019/2020.

Berdasarkan simpulan dan implikasi penelitian yang telah dipaparkan, maka dapat diajukan beberapa saran guna peningkatkan kualitas pembelajaran IPA sebagai berikut.

a. Kepada Guru

Hasil penelitian menunjukkan bahwa siswa yang mengikuti pembelajaran dengan pendekatan saintifik dengan metode PQ4R secara signifikan memiliki minat literasi humanistik dan hasil belajar IPA yang tinggi daripada siswa yang mengikuti pembelajaran konvensional. Oleh karena itu, para guru disarankan menggunakan pendekatan saintifik dengan metode PQ4R dalam pembelajaran di sekolah untuk meningkatkan minat literasi humanistik dan hasil belajar IPA.

b. Kepada Kepala Sekolah Hendaknya kepala sekolah merancang atau memanajemen 
proses pembelajaran yang terjadi di sekolah menggunakan pendekatan dan metode pembelajaran yang inovatif, khususnya pendekatan saintifik dengan metode PQ4R, agar dapat meningkatkan kualitas proses pembelajaran di sekolah tersebut.

c. Kepada Peneliti Lain

Mengingat keterbatasan waktu dan pokok bahasan yang digunakan dalam penelitian ini, maka disarankan kepada peneliti lain, agar melaksanakan penelitian sejenis dengan pemilihan materi yang berbeda dan waktu yang lebih lama untuk mendapatkan gambaran yang lebih meyakinkan mengenai pendekatan saintifik dengan metode PQ4R terhadap minat literasi humanistik dan hasil belajar IPA. Untuk penyempurnaan penelitian ini, disarankan kepada peneliti lain untuk mengadakan penelitian lanjut dengan melibatkan variabel-variabel lain, misalnya motivasi belajar, kemampuan berpikir kritis dan lain sebagainya.

\section{DAFTAR RUJUKAN}

Agung, Gede. 2014. Metodologi Penelitian Pendidikan. Malang: Aditya Media. Publishing.

Astiti, Kadek Ayu. 2017. Evaluasi Pembelajaran. Yogyakarta: Andi Offset.

Astuti, Yani Kusuma. 2016. Literasi Sains Dalam Pembelajaran. e Journal Universitas Wiralodra.

Candiasa, I Made. 2010. Statistik Multivariat Petunjk Analisis dengan SPSS. Program Pasca Sarjana Universitas Pendidikan Ganesha Singaraja.

Faradita. 2019. Peningkatan Hasil Belajar IPA di SD dengan Menggunakan Metode PQ4R. Jurnal Bidang Pendidikan Dasar. 3(1), 7-13.

Juniawan, Made Edy. 2020. Pengaruh Pembelajaran Saintifik Berbasis Literasi Terhadap Kemampuan Membaca Pemahaman Dan Hasil
Belajar Pelajaran Kelompok Sosial Humaniora Siswa Kelas V SD Di Gugus 1 Kuta. PENDASI: Jurnal Pendidikan Dasar Indonesia. Vol 4, No 1.

Kemendikbud. 2016. Jendela Pendidikan Dan Kebudayaan Gerakan Literasi Untuk Tumbuhkan Budaya Literasi. Jakarta: Kementerian Pendidkan dan Kebudayaan.

Koyan. 2011. Asesmen dalam Pendidikan. Singaraja: Universitas Pendidikan Ganesha Press.

Miftakhurrofi'ah. 2018. Pengaruh Perangkat Pembelajaran Berbasis Strategi PQ4R Terhadap Motivasi Dan Hasil Belajar Kognitif Peserta Didik. E-Journal Pendidikan IPA. Volume 7 No 8 Tahun 2018.

Oktavianti, Ika, dkk. 2017. Menggagas Kajian Budaya Lokal Di Sekolah Dasar Melalui Gerakan Literasi Sekolah. Prosiding seminar nasional. aktualisasi kurikulum 2013 di sekolah dasar melalui gerakan literasi sekolah untuk menyiapkan generasi unggul dan berbudi pekerti. 15 maret 2017. Google Scholar.

Puspita. 2015. Strategi Membaca PQ4R. Online. Tersedia Pada: http://www.kajianpustaka.com/2015/ 01/strategi-membaca-pq4r.html. Diakses pada 10 Maret 2020.

Rihi, Marince. dkk. 2018. Pengaruh Model Pembelajaran Student Teams Achievement Devisions (STAD) Terhadap Hasil Belajar Siswa Pada Mata Pelajaran Matematika Kelas VII. Prosiding Seminar Nasional Pendidikan Matematika Etnomatnesia (2018).

Rikmasari. 2018. Metode Pembelajaran PQ4R dalam Meningkatkan Kemampuan Membaca Pemahaman Siswa Kelas V di Bekasi. JMIE. Journal of Madrasah Ibtidaiyah Education, 2 (2). 2018. 265-275.

Supriya. 2009. Pendidikan IPS: Konsep dan Pembelajaran. Bandung: Rosda Karya. 
Susanto, Ahmad. 2007. Teori Belajar Pembelajaran di Sekolah Dasar. Jakarta: Prenadamedia Group.

Trianto. 2007. Model-model Pembelajaran Inovatif Berorientasi Kontruktivistik. Jakarta: Prestasi Pustaka.

Trianto. 2010. Model Pembelajaran Inovatif-Progresif Konsep, Landasan, dan Implementasi Pada Kurikulum Tingkat Satuan Pendidikan (KTSP). Jakarta: Kencana.

Wahida, Fefri. 2016. Hubungan Antara Minat Belajar Matematika Dengan Hasil Belajar Matematika Peserta Didik Kelas VIII SMP Negeri 1 Sungguminasa Kabupaten Gowa: Skripsi. UIN Alauddin Makassar.

Wijayanto, Jejen. 2018. Implementasi Model Pembelajaran PQ4R Dengan Pendekatan Saintifik Pada Peningkatan Kemampuan Pemecahan Masalah Matematis Siswa. Jurnal Penelitian Didaktik Matematika. Vol: 1, No. 1, April 2018.

Winataputra, Udin S. 2008. Teori Belajar dan Pembelajaran. Jakarta: Universitas Terbuka.
Windyariani. 2016. Pengembangan Bahan Ajar Berbasis Konteks dan Kreativitas untuk Melatihkan Literasi Sains Siswa Sekolah Dasar. Jurnal Bioedukatika. Vol 4, No 2 (2016). 